\title{
nombalina
}

(8)

\section{“In learned conversation”: Plutarch's symposiac literature and the elusive authorial voice}

\author{
Autor(es): $\quad$ Brenk, Frederick E. \\ Publicado por: Imprensa da Universidade de Coimbra; Centro de Estudos Clássicos e \\ Humanísticos \\ URL \\ persistente: \\ URI:http://hdl.handle.net/10316.2/31977 \\ DOI: \\ DOl:http://dx.doi.org/10.14195/978-989-8281-17-3_5 \\ Accessed : $\quad$ 26-Apr-2023 06:13:11
}

A navegação consulta e descarregamento dos títulos inseridos nas Bibliotecas Digitais UC Digitalis, UC Pombalina e UC Impactum, pressupõem a aceitação plena e sem reservas dos Termos e Condições de Uso destas Bibliotecas Digitais, disponíveis em https://digitalis.uc.pt/pt-pt/termos.

Conforme exposto nos referidos Termos e Condições de Uso, o descarregamento de títulos de acesso restrito requer uma licença válida de autorização devendo o utilizador aceder ao(s) documento(s) a partir de um endereço de IP da instituição detentora da supramencionada licença.

Ao utilizador é apenas permitido o descarregamento para uso pessoal, pelo que o emprego do(s) título(s) descarregado(s) para outro fim, designadamente comercial, carece de autorização do respetivo autor ou editor da obra.

Na medida em que todas as obras da UC Digitalis se encontram protegidas pelo Código do Direito de Autor e Direitos Conexos e demais legislação aplicável, toda a cópia, parcial ou total, deste documento, nos casos em que é legalmente admitida, deverá conter ou fazer-se acompanhar por este aviso.

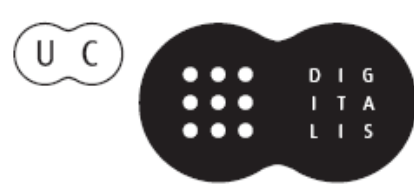




\section{Symposion and Philanthropia in Plutarch}

\section{José Ribeiro Ferreira, Delfim Leão Manuel Troster e Paula Barata Dias (eds.)}

IMPRENSA DA UNIVERSIDADE DE COIMBRA 


\title{
“In learned conversation”. Plutarch's symposiac LITERATURE AND THE ELUSIVE AUTHORIAL VOICE
}

\author{
Frederick E. Brenk \\ Pontifical Biblical Institute of Rome
}

\begin{abstract}
The Symposiacs offer a good entry point for understanding Plutarch's dialogues. Plato's, such as the Symposion, are often used as a model to interpret Plutarch's without consideration of the changed circumstances in the Imperial period. Also, toward the end of Plato's life, his dialogues became treatises in which the interlocutors are hardly important. Plutarch used no single character throughout his dialogues. Like Cicero he wanted to present the opinions of the philosophical schools, and often his own position is difficult to discern. The role and importance of various persons in the spirited intellectual discussions of the Symposiacs offer a clue to his intentions in the dialogues. At the same time, unlike his dialogues, his own persona appears frequently and with a surprising assertiveness. In some Symposiacs, especially the Ninth Book, as in The E at Delphoi and the Erotikos, he appears as fairly young, possibly a distancing technique. The Symposiacs in any case offered an opportunity to present his views in various shapes and sizes.
\end{abstract}

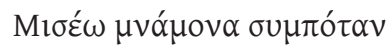

I hate a fellow drinker with a good memory. (opening of the Symposiacs) ${ }^{1}$

This citation from an unknown poet, used to open the Symposiacs, pretty well destroys our approach to the theme of the symposion if not of philanthropia. Perhaps we should not try to remember what occurs in a drinking party ${ }^{2}$. However, with a good memory for Plutarch's Symposiacs (Quaestiones convivales), one can possibly come closer into the circle of his friends and get a better understanding of the authorial voice not only in the Symposiacs but also in his major dialogues ${ }^{3}$. Perhaps none of the personae who appear in Plutarch's dialogues, not even the persona Plutarch, completely represents his thought. For example, in the Erotikos, by presenting himself as a newlywed, many years before, he is able to convey to his readers a certain distance between himself and the person $a^{4}$. Throughout his writings Plutarch indicates that he is searching for the true voice of Plato among his different speakers and dialogues. Undoubtedly Plutarch's readers, too, were searching

${ }^{1}$ Symposiacs 612C; D. A. Campbell, 1993, p. 405, Anonymous, no. 1002. He lists three other authors who cite it, including Lucian, Symposion 3, and notes an allusion to the saying in Martial, 1.27.7. See the indispensable commentary of S.-T. Teodorsson, 1989-1996, I., pp. $31-2$.

${ }^{2}$ Actually at 6.1 (686D) Plutarch gives just the opposite advice, the necessity of remembering the discussions, something which justifies his own writing of the Symposiacs.

${ }^{3}$ On Plutarch's friends, see F. Funrmann, 1966,pp.65-7; B. Puech, 1992; S.-T.Teodorsson, 1989-1996; and E. N. O’NeIL, 2004.

${ }^{4}$ Here the views of S. Goldhill, 1995, and J. M. Rist, 2001, represent rather opposite ends of the spectrum of interpretation. 
for guidance, and the present tendency in Plutarchan scholarship, as in the recent work of Jan Opsomer, is to try to identify his own position. Plato's dialogues, such as his Symposion, are often used as the model with which to interpret Plutarch's, but Plutarch's often require a different methodology5. Oddly enough, Plato composed even one of his latest works, the Timaios, a long treatise which turns into a monologue and in which Socrates has only a minor part, as a symposion ${ }^{6}$. In general, at least during his early and middle periods, Plato's Socrates remained his principal spokesman. Moreover, the speeches of the minor characters seem to work together with his to form an artistic whole 7 . Toward the end of Plato's life, his dialogues became treatises in which the interlocutors change and lose importance. On the other hand, Plutarch used no single character as his spokesman, so that his own position is difficult to discern. Where he wrote treatises without the pretense of a dialogue, his position is clear. However, the dialogues remain very problematic. His Symposiacs are a good example of lively discussions of different opinions among many speakers, often without necessarily indicating his own belief. As so often in studying authors of the Imperial period, we have in our minds the literature of the fifth or fourth centuries B.C., without always taking into account the great changes that took place by the Imperial period. Not only did Plutarch not use a single main speaker like Socrates through several dialogues, but those who do appear often make no second appearance. On one rare occasion when he appears himself as a persona and as the principal speaker in a dialogue, in the Erotikos (Dialogue on Love, Amatorius), even the views of his own persona are very problematic ${ }^{8}$. In contrast to the dialogues, though, in the Symposiacs Plutarch often appears as a final or principal speaker. In fact, his own role is astoundingly forceful. His voice seems particularly strong in the opening of the books of the Symposiacs, where, after the preface to the dedicatee, Sosius Senecio, we find rather long "questions", really small treatises. However, apart from the opening questions there are other quite extensive ones, perhaps for variety, or perhaps because they needed more development. At any rate an advantage of the genre is the possibility to craft a particular question as brief or long as desired, and to inject or omit the author's persona at any point.

Cicero's philosophical dialogues bear a striking lack of resemblance to Plato's and in many respects are much closer to some of Plutarch's. This may be partially due to the philosophical allegiance of both to "the Academy". In

${ }^{5}$ For Plato, see, e.g., R. B. Rutherford, 1995, pp. 180-205, 305-6; C. Gill, 2002, esp. pp. 147-9 and 161-4; R. Hunter, 2004; and C. J. Rowe, 2007. For Xenophon, see D. L. GerA, 1993, pp. 132-54. An excellent discussion of Plutarch's relationship to Plato and the use of characters to develop his own views can be found in J. M. Rist, 2001, esp. 558-61.

${ }^{6}$ See the excellent contribution of M. Tecuşan, 1990, esp. p. 243. She discusses Plato's changing attitude toward the value of the symposion (esp. pp. 244, 246, 255-60).

${ }^{7}$ D. Babut, 1992 repr. in D. Babut, 1994, pp. 457-501. F. Frazier, 2006, has criticized the approach of F. ILDEFonse for an interesting twist in interpreting Plato, see F. C. WHITE, 2008, who holds that Alkibiades' speech is more important than that of Diotima.

${ }^{8}$ So S. Goldhill, 1995 , pp. 159-60. 
Cicero the principal thrust seems to be presenting the opinions of the major philosophical schools, favoring and criticizing certain views on the way, but in general allowing the representatives of the schools to speak their minds ${ }^{9}$. Langlands, who attributes it to the rhetorical tradition, has noted how fond Romans were of being subjected to contradictory opinions before choosing the best or coming to their own solution ${ }^{10}$. We must imagine that the dedicatee of the Symposiacs, who also participates as a persona in them, Sosius Senecio, was one of these Romans. This practice contrasts at times with Plutarch's voice in the Symposiacs where his own persona often goes on at length or decides the question, and is similar to his tractates, such as On the Generation of the Soul in the Timaios (De animae procreatione in Timaeo), where his position is crystal clear. We have something similar to the Symposiacs in Aulus Gellius, Athenaios, and in the parody of the genre in Lucian's Symposion (or Dinner of the Lapiths) ${ }^{11}$. Evidently one of the major purposes of the philosophical symposion was to introduce the reader to the most prominent philosophical views of the time and discuss them, often in a critical fashion. In more philosophical dialogues such as Cicero's the reader would then be given guidance on how to evaluate the opinions. Though Lucian's Symposion is a rather sadistic farce, reading between the lines one can imagine a serious philosophical symposion of the time ${ }^{12}$.

Where we have something like Cicero's extended philosophical dialogues is in individual tractates, where Plutarch writes in his own person. In this case he clearly states his views (and often, naturally, misrepresents those of the adversary). Often more polemical than Cicero, he usually defends the Platonic position and attacks Stoic or Epicurean ones. He belongs in these cases to his time, reflecting the debates between the well-established schools. On the Face in the Moon (De facie in orbe lunae) begins very much in dialogue form, with the presentation of various opinions. But then it branches out into a treatise, with one speaker developing the central view or thesis and accompanying it with an eschatological myth. In this case, which resembles Plato's Timaios in its format, the main speaker is Plutarch's brother Lamprias. We are thus left wondering again about what might have been Lamprias' contribution ${ }^{13}$.

\footnotetext{
${ }^{9}$ See e.g., P. G. Walsh, 2000, esp. p. xvi, who speaks of Cicero's "intensive reflection" on the central concerns of the Hellenistic schools as viewed by their spokesmen. The Tusculan Disputations, something like Plutarch's Symposiacs, supposedly took place each on a different day. For the complexities of his presentation of the Hellenistic schools, see C. LÉvy, 2008, pp. 1-5, and in the same volume, pp. 5-20.

${ }^{10}$ R. Langlands, 2009, esp. pp. 160-3.

${ }^{11}$ Gellius claimed that his discussions were a shortcut to a general education for those too busy for much study, Preface, 11-12. On Aulus Gellius, see L. Holford-Strevens, 1988, esp. 27-32 (27) (rev. ed., 2003); W. H. Keulen, 2009, pp. 2-14, 240, 253, 279, 282, 288-92, 300, stressing the difference between the Roman and Greek intellectual worlds at the time. She rejects (p. 8) what she sees in S. Swain, 2004, pp. 17, 20, 35 as a "deflating picture of Latin intellectuals".

12 On the contrast between this and Plutarch's Symposiacs, see J. Hall, 1981, esp. pp. 204-5; C. P. Jones, 1986, pp. 28-41; R. Bracht Branham, 1989, pp. 108-10; I. Männlein, 2000. F. Frazier, 1994, pp. 125-30, takes a much harsher view of Lucian than Bracht Branham.

${ }^{13}$ On Lamprias, see D. A. Russell, 1973, pp. 4, 69, 71-3; and C. P. Jones, 1971, pp. 9-10.
} 
In the very first book of the Symposiacs, Plutarch remarks that if only philosophically inclined persons are present, philosophy would be a suitable topic, but if not, many would be excluded. For this reason, the topics must be familiar, simple, and easy (614D) ${ }^{14}$. Petronius' "Dinner of Trimalchio" in his Satyrica (Satyricon) can give valuable insights, in spite of it being satirical. The work was written earlier than Plutarch's Symposiacs but within his lifetime, satirizing the attempt of nouveau-riches, who ape intellectual discussions and presumably in the attempt to carry on a kind of symposion. Several of the themes satirized are similar to those we find in the Symposiacs, ranging over natural phenomenon, religion, what we might call pseudo-science, popular philosophy, and the like ${ }^{15}$. In any case, Plutarch's Symposiacs do not descend to the level of a "commonplace book" such as typifies much of Aulus Gellius and Athenaios, nor are they anything like the sadistic farce of Lucian's Symposion. Examination of the dialogues of Aulus Gellius, Athenaios, and Lucian quickly reveals how distant they are not only from Plato, but even from Plutarch ${ }^{16}$. At the same time these works give us good insights into the genre Plutarch used.

The novel creation of the persona, the newly married Plutarch as recounted by his son, in the Erotikos, allowed him more freedom to present provocative and problematic views. These contrast with his own traditional views of love and marriage elsewhere and permitted him, intentionally or not, to gain an enviable place in "the history of sexuality". But even in this dialogue, where the final views are presumably those of the author, other speakers initially have their say. Their speeches on heterosexual or homosexual love are quite aggressive, but one could perhaps point to their "propedeutic" function rather than their "tonality"17. As in the Symposiacs, such a strong projection of opposing views seems to have satisfied a desire in the readers to participate vicariously in spirited, contemporary intellectual discussion. The views presented here raise serious problems, enough so as to wonder whether Plutarch is not just being ironic, or problematic, or over-influenced by other genres, such as that of comedy ${ }^{18}$.

${ }^{14}$ O. Murray, 1990, p. v, citing Moralia 629D, notes the difference between sympotika (talk about the symposion) and symposiaka (talk suitable for the symposion).

${ }^{15}$ See, e.g., F. Dupont, 2002, pp. 61-114, popular, but covering the major works.

${ }^{16}$ Gellius had read Plutarch and mentions him at the beginning of his work 1.1.1. On Gellius, see L. Holford-Strevens \& A. Vardi (eds.), 2004, esp. pp. 10-4; and in the same volume A. VArdi, esp. pp. 183-6. On Athenaios see A. Lukinovich, 1990, esp. pp. 265-7; D. Braund \& J. Wilkins (eds.), 2000, esp. J. Wilkins, pp. 23-40; L. Romeri, pp. 256-71; and G. Anderson, pp. 316-27; also S.-T. Teodorsson, 1989-1996, I, p. 12, who finds the closest parallels to be Athenaios, Deipnosophists and Macrobius Saturnalia, the latter of which he takes to be an imitation of Plutarch.

${ }^{17}$ See, e.g., J. M. Rist, 2001, esp. pp. 560-61.

${ }^{18}$ J. M. Rist, 2001, esp., p. 558, sees Plutarch building up, through the speeches, a very complicated and sophisticated conception of love. This in Rist's view represents a kind of "commentary" on Plato's theories, which he sees primarily as those of the Phaidros. I am grateful to Ann Chapman for having seen her forthcoming dissertation. She treats Plutarch's views as not very favorable toward women. See also F. E. BRENK, 2007. 
For this reason, a good place to start is Plutarch's Symposiacs (or Table Talk, Quaestiones convivales), where we also have the dominant persona of Plutarch, including that of his youth. With the exception of his Symposiacs few of his works have a symposiac setting in the strict sense. The notable exception is the Symposium (or Dinner of the Seven Sages (Septem sapientium convivium) ${ }^{19}$. However, the themes treated are not normal, at least for the extant Classical or Imperial symposia, and may be too traditional in scope to say much about Plutarch's originality or emphasis. Nonetheless, Mossman finds a number of original elements, such as the selection of Sages, the introduction of Aesop and the women (the clever Kleoboulina and Melissa), and probably the story of Arion and the dolphin, not to speak of the deliberate omission of homosexual themes and substitution of heterosexuality ${ }^{20}$. To Mossman's list one could add the emphasis on divine providence at the end of the work. She points out that the Dinner of the Serven Sages and The Daimonion of Socrates (De genio Socratis) are the only works which Plutarch set in the distant past. The Erotikos, a very late dialogue of Plutarch, might qualify as a Platonic symposion if we consider its theme. But the mise-en-scène is not a symposion, daimones do not appear, there is only a hint of love being directed to the intelligible world, the denouement involves heterosexual love, and a very unusual marriage is played out before one's eyes. In The Daimonion of Socrates, the principals are in an indoor setting and daimones, so prominent in Plato's Symposion, play a major role, but the occasion is never called a symposion, or even a dinner, and the participants' major purpose for being there is their involvement in a bloody revolt against the Spartan overlords at Thebes ${ }^{21}$.

Perhaps we can look at some particulars at the end of the Symposiacs, the Ninth Book from Plutarch's student days. These are the last Symposiacs he wrote, though the recollections, whether fictional or real, chronologically would come first. They may recall real discussions held at the time, possibly in the Academy, but some topics seem suspiciously generic. The speakers appear to be real persons and possibly at least some of the speeches may represent what they actually said ${ }^{22}$. As in other Symposiacs, though, it is impossible to determine, especially if the topic is a common theme, whether any speech is an invention or real ${ }^{23}$. In some other Symposiacs Plutarch is presented as quite young, appearing in what should be the commanding company of Ammonios, his philosophy professor, with his father, or even his grandfather. Most of the Symposiacs are not very philosophical by our standards, often resolving folkloric questions about natural phenomena

${ }^{19}$ On this see the excellent study by J. M. Mossman, 1997; also D. E. Aune, 1972; S. Jedrkiewicz, 1997, review, F. E. Brenk \& F. Lo Cascio, 2000; A. Busine, 2002; and D. L. LEÃO, 2005.

${ }^{20}$ J. M. Mossman, 1997, esp. pp. 124-6, 133-4.

${ }_{21}$ Perhaps to contrast with the dinner (deipnon) in which Archias, the commander, is assassinated (588B). Phyllidas uses wine and food as part of his trap for Archias (596C), "at the hour when most people are at dinner".

${ }^{22}$ See S.-T.Teodorsson, 1989-1996, III, pp. 299-300, on the unusual qualities of this book of the Symposiacs compared to his others.

${ }^{23}$ S.-T. TeOdonsson, 1989-1996, I, pp. 12-5, stresses the element of authenticity. 
or presumed natural phenomena, with, to us, pseudo-scientific guesswork ${ }^{24}$. Eleni Kechagia has suggested that through them Plutarch was instructing the reader to think like a philosopher. Certainly there is a methodology at stake: verification of the data, exploration of various possibilities, citation of the experts (like Aristotle), testing and debating of the data and opinions, subjection of the result to common sense, and attestation of parallel phenomena. Sometimes the result seems ridiculous, but some of the Symposiacs, for example, on whether fish or meat is better for one's health could stand up well today.

The Symposiacs offer information on the speakers and their importance, and, thus, on the possible authorial voice of Plutarch in his other dialogues. Most surprising is his own commanding role. Of a total of 72 Symposiacs useful for this purpose, Plutarch astoundingly, is the principal speaker in 33, or almost half, at least in the sense of having the final word. In 39 cases either he is absent or yields the ground to another speaker who has the principal or final word. In a couple of them Plutarch has a rather extensive speech, as in 2.1, which goes on for 15 (Loeb) pages ${ }^{25}$. However, in the later books the first question becomes much shorter. Sometimes he defers to important personages such as Sosius Senecio, to whom these books and the Lives were dedicated, or to his former teacher Ammonios ${ }^{26}$. Though invited to do so by Ammonios, he has no complexes about developing a long and rather convincing counterargument to his teacher's proposition about ivy being hot (3.2). He also has no qualms about taking on a respected physician on a medical matter (7.1). Nor does he go completely unopposed. In Symposiac 1.9, his friend Theon comes close to calling him "full of baloney". Thus, half the time, we search for the authorial voice, looking for Plutarch in disguise. But would his own persona utter opinions he never subscribed to, even the brilliant nonsense of his youth in The E at Delphoi (De E apud Delphos)? At times he seems sympathetic to a principal speaker's views. Sometimes his persona even says so. In most cases, though, his mind remains a little inscrutable.

Several of the speakers who appear in later dialogues make possibly their first appearance in the Symposiacs. Among these are his brother Lamprias and two friends named Theon, one of whom is called his "companion". Then there is Ammonios, and naturally, Plutarch himself. In the dialogues, Plutarch appears as a young student in The E at Delphoi, as a philosophy professor in That Epicurus Actually Makes Life Impossible, and as a young married man in the Dialogue on Love. The Theon who is a grammarian from Egypt appears in The Face on the Moon. The other, the "companion" - and according to Puech, Plutarch's most constant friend in the Moralia - is a participant in both The E at Delphoi and The

${ }^{24}$ S.-T.Teodorsson, 1989-1996, III, pp. 299-300, notes that the 9th book is an exception in treating only musical, literary and philological question, and that all the discussions take place during the festival of the Muses in Athens.

${ }^{25}$ Perhaps he thought Senecio might read the first question but not the others.

${ }^{26}$ On Sosius Senecio, spelled Sossius by Plutarch, see B. Puech, 1992, pp. 4883-5; on Ammonios, 4835-6; and C. P. Jones, 1966, pp. 205-11. 
Oracles at Delphoi (De Pythiae oraculis) ${ }^{27}$. In the latter he is the principal speaker, whose speech takes up 20 pages of the dialogue. He appears as well in A Pleasant Life is Impossible (Non posse suaviter vivere secundum Epicurum). Plutarch's brother Lamprias has a minor role in The $E$ at Delphoi. It is easy to forget that here, though the young Plutarch is reprimanded for a little wisdom being a dangerous thing, he has a longer speech than the sublime one of his teacher Ammonios, which concludes the dialogue. In The Obsolescence of Oracles (De defectu oraculorum) Ammonios plays quite a prominent role. He guides the conversation and prefers the theory that daimones are souls. Nonetheless, Lamprias is the principal speaker and offers the final solution to the cause of the prophecy. This involves, strangely, a physical emanation coming from the ground at Delphoi. He also appears in The $E$ at Delphoi (De E apud Delphos) and is, amazingly, the narrator and principal speaker in The Face on the Moon. Thus, the cast of characters of the dialogues bears a strong resemblance to some of the Symposiacs. Lamprias has the last word in three of them $(1.2,2.5,4.5$, and 8.6) is the main speaker in three or four $(2.9,5.9$, and 7.5, and possibly in 7.10). Most remarkably, Ammonios is a relatively minor character in the Symposiacs, considering his intellectual and political stature in real life and his enormous theological role in The E at Delphoi. He is the principal speaker in only two Symposiacs (9.1 and 9.14) and is only one among others in another two (9.2 and 9.5).

Plutarch's readers, like all Greeks and Romans, as we are often told, had better memories than we, whose computers do our remembering for us. Thus, judging by the Symposiacs alone, Lamprias lacks prestige and is sometimes on the wrong side. He might have been the author of the materialistic solution to the functioning of prophecy in The Obsolescence of Oracles, but how could he be responsible for the great scientific exposition in The Face on the Moon? Certainly Plutarch's friends would have immediately recognized him behind the mask of Lamprias. More problematic is how to interpret Ammonios, the great Alexandrian theologian who pronounces such sublime doctrine at the end of The E at Delphoi, identifying God with Being and the Good ${ }^{28}$. $\mathrm{He}$ is not such a commanding figure in the Symposiacs, but his philosophical stature would permit him to have a commanding voice. In this case there might have been something of a compromise. Reading his speech in the $E$ at Delphoi, Plutarch's friends would certainly expect to find some resemblance to Ammonios' real teaching. They might have wondered, too, why Plutarch left him on the sidelines so long. One suspects an attempt to keep some distance between his philosophy and Ammonios ${ }^{29}$.

${ }^{27}$ See B. Puech, 1992, p. 4886. Others are less certain about their roles; see P. A. Clement, 1969 , pp. 48-9, note b.

${ }^{28} \mathrm{~J}$. Opsomer, 2007, sees the topics of the Platonic Questions being picked up and developed in the dialogues, e.g. The $E$ at Delphoi, including the deliberate introduction of errors to be corrected. In this case, Ammonios carries on the role that Plutarch had in the Platonic Question (5). In the end useful or worthy aspects of the false views will be incorporated into the final, superior solution, at times one original with Plutarch (esp. ms. pp. 17-20). For the position of the Symposiacs in this, see ms. p. 17.

${ }^{29}$ See my forthcoming article, "Proceeding to Loftier Heights': Plutarch the Theologian and 
The role of Theon, the Egyptian grammatikos, who appears in only two Symposiacs (1.9 and 8.8), might barely allow him to be a speaker in The Face on the Moon. The other Theon, the "companion" of Plutarch, whom we find in only three Symposiacs $(1.4,4.3,8.6)$, surprisingly appears in the $E$ at Delphoi, The Oracles at Delphoi, and That Epicurus Makes a Pleasant Life Impossible. That he should be such an authoritative figure in The Oracles at Delphoi, with the final and definitive speech of 18 pages, comes as a great surprise. Certainly the suspicions of Plutarch's readers and friends would also be aroused by Kleombrotos, the Spartan friend, who describes the daimones in such horrendous terms in The Obsolescence of the Oracles, and receives 17 pages $^{30}$. He appears in no other work, including the Symposiacs, but his Frankensteinian exposition has captivated the imagination of great religious scholars (410C-F, 414F-418D). The Stoic Sophist, Philippos of Prousias on the Hypios in Bithynia is responsible for the story of the death of the Great Pan off the Island of Paxos (near the present Corfu) in the Ionian Sea (419B-E) ${ }^{31}$. He is the only speaker in 7.7 and has a few words in 7.8, but appears nowhere else in Plutarch's works ${ }^{32}$. What goes for Kleombrotos applies as well for Demetrios of Tarsos, a grammarian friend of Plutarch's, responsible for the story of the "Great Souls" dying off the coast of the British Isles (6 pages) (419E-420A). He, too, is absent from the Symposiacs and appears nowhere else in the Moralia ${ }^{33}$.

In conclusion a bad memory may be a plus for drinking partners, who usually have bad memories anyway and sometimes even complete amnesia. But let us opt for Plutarch in Symposiac 6.1, where he champions the necessity to remember the philosophical discussions which occur in symposions and even to record them. Thus justifying the reason for their existence, he has passed on the Symposiacs to posterity, including us, even if leaving the vague impression that all was not, strictly speaking, "recorded".

\section{WORKS CITED}

Anderson, G., "The Banquet of Belles-Lettres: Athenaeus and the Comic Symposium”, in D. Braund \& J. Wilkins (eds.), 2000, pp. 316-27.

Aune, D. E., "Septem Sapientium Convivium”, in H. D. Betz (ed.), Plutarch's Theological Writings and Early Christians Literature, Leiden, 1972, pp. 51-105.

the Philosophy of His Time”, in E. Kechagia (ed.), Plutarch and Philosophy. Scholarship and/or Dilettantism?, forthcoming.

${ }^{30}$ B. Puech, 1992, p. 4843, presumes he was a companion, in the ephebeia, of the Philippos who was ephor of Sparta in 87/89 A.D.

${ }^{31}$ Prousias, not Prousa. O'Neil's index for the Moralia still gets it wrong.

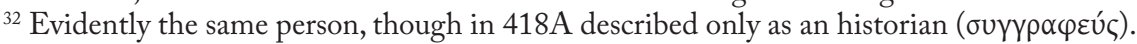
See B. Puech, 1992, pp. 4869-70, but her remark (p. 4870) about him mentioning Bithynia in On the Oracles at Delphoi seems to be mistaken.

${ }_{33}$ B. Puech, 1992, pp. 4844-5, has a long entry on Demetrios. 
Babut, D., "La composition des Dialogues de Plutarque et le problème de leur unité", JS 27 (1992) 187-234. Parerga. Choix d'articles de Daniel Babut (1974-1994), Lyon, 1994.

Bracht Branham, R., Unruly Eloquence. Lucian and the Comedy of Traditions, Cambridge, Mass., 1989.

Braund, D. \& Wilkins, J. (eds.), Athenaeus and His World. Reading Greek Culture in the Roman Empire, Exeter, 2000.

Brenk, F. E. \& Lo Cascio, F., Review of S. Jedrkiewicz, Il convitato sullo sgabello. Plutarco, Esopo ed i Sette Savi, Pisa/Rome, 1997 in CR, 50 (2000) 286-87.

Brenk, F. E., "Uttering Unperfumed Words, Yet Reaches to a Thousand Years with Her Voice.'Plutarch and His Age", in idem (ed.), With Unperfumed Voice. Studies in Plutarch, in Greek Literature, Religion and Philosophy, and in the New Testament Background, Stuttgart, 2007, pp. 17-51. (Italian version: "Parlando senza profumi raggiunge con la voce mille anni.' Plutarco e la sua età", in P. Volpe Cacciatore \& F. Ferrari (eds.), Plutarco e la cultura della sua età, Naples, 2007, pp. 11-38.)

Busine, A., Les Sept Sages de la Grèce Antique. Transmission et utilisation d'un patrimoine légendaire d'Hérodote à Plutarque, Paris, 2002.

Campbell, D. A., Greek Lyric Poetry V. The Nerw School of Poetry and Anonymous Songs and Hymns, Cambridge, Mass., 1993.

Clement, P. A., Plutarch's Moralia VIII, Cambridge, Mass., 1969.

Dupont, F., Le plaisir et la loi. Du Banquet de Platon au Satiricon, Paris, 2002.

Frazier, F., "Deux images des Banquets de Lettrés: les Propos de Table de Plutarque et le Banquet de Lucien", in A. Billault (ed.), Lucien de Samosate, Lyon, 1994, pp. 125-30.

Review of F. Ildefonse, Dialogues pythiques. L'E de Delphes, Pourquoi la Pythie ne rend plus ses oracles en vers, La disparition des oracles, Paris, 2006, in Ploutarchos, 5 (2007-2008) 114-21.

Fuhrmann, F., "Les amis romains de Plutarque d'après les Propos de table", REL, 44 (1966) 65-67.

Gera, D. L., Xenophon's Cyropaedia. Style, Genre, and Literary Technique, Oxford, 1993.

Gill, C., "Dialectic and the Dialogue Form", in J. Annas \& C. Rowe (eds.), New Perspectives on Plato, Modern and Ancient, Cambridge, Mass., 2002, pp. 145-72.

Goldhill, S., Foucault's Virginity. Ancient Erotic Fiction and the History of Sexuality, Cambridge, 1995. 
Hall, J., Lucian's Satire, New York, 1981.

Holford-Strevens, L., Aulus Gelius, Chapel Hill, 1988. Aulus Gellius. An Antonine Scholar and his Achievement, Oxford, 2003 (rev. ed.). \& VArdi (eds.), A., The Worlds of Aulus Gellius, Oxford, 2004

Hunter, R., Plato's Symposium, Oxford, 2004.

Jedrkiewicz, S., Il convitato sullo sgabello. Plutarco, Esopo ed i Sette Savi, Pisa and Rome, 1997.

Jones, C. P., “The Teacher of Plutarch”, HSCP, 71 (1966) 205-11.

Plutarch and Rome, Oxford, 1971.

Culture and Society in Lucian, Harvard, 1986.

Keulen, W. H., Gellius the Satirist. Roman Cultural Authority in Attic Nights, Leiden, 2009.

Langlands, R., "Reading for the Moral' in Valerius Maximus: The Case for Severitas", CCJ, 54 (2009) 160-87.

Leão, D. F., "Plutarco e a tradição dos Sete Sábios", in M. Jufresa et AL. (eds.), Plutarc a la seva època: Paideia i societat. Actas del VIII Simposio español sobre Plutarco (Barcelona, 6-8 de Noviembre, 2003), Barcelona, 2005, pp. 235-42.

Lévy, C., "Présentation", in C. Lévy (ed.), Cicéron, Paris, 2008 (=Revue de Métaphysique et de Morale 1 [2008]), pp. 1-5.

"Cicéron, le moyen platonisme et la philosophie romaine: à propos de la naissance du concept latin de qualitas", in C. LÉvy (ed.), Cicéron, Paris, 2008, pp. 5-20.

Lukinovich, A., "The Play of Reflection between Literary Form and the Sympotic Theme in the Deipnosophistae", in O. Murray (ed.), 1990, pp. 263-71.

Männlein, I., "What Can Go Wrong at a Dinner Party: the Unmasking of False Philosophers in Lucian's Symposium or the Lapiths", in K. Pollmann (ed.), Double Standards in the Ancient and Medieval World, Göttingen, 2000, pp. 247-59.

Mossman, J. M., "Plutarch's Dinner of the Seven Wise Men", in J. M. Mossman (ed.), Plutarch and His Intellectual World, London, 1997, pp. 119-40.

Murray, O. (ed.), Sympotica. A Symposium on the Symposion, Oxford, 1990.

O’Neil, E. N., Plutarch, Moralia XVI. Index, Cambridge, Mass., 2004. 
Opsomer, J., "Plutarch on the One and the Dyad", in R. Sorabji \& R. W. Sharples (eds.), Greek and Roman Philosophy 100 BC-200 AD, London, 2007, pp. 379-95.

"Sur les arguments non rectilignes et la pensée par cercles. Forme et argumentation dans les Quaestiones Platonicae", in X. Brouillette and A. Giavatto (eds.), Les dialogues platoniciens chez Plutarque. Stratégies et méthodes exégétiques, Leuven, University Press (Ancient and Medieval Philosophy. Series 1) forthcoming.

Puech, B., "Prosopographie des amis de Plutarque", ANRW II.33.6 (1992) 4831-93.

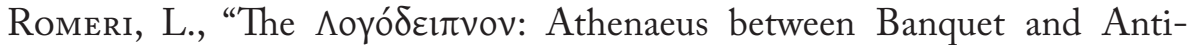
Banquet", in D. Braund \& J. Wilkins (eds.), 2000, pp. 256-71.

Rist, J. M., "Plutarch's Amatorius: A Commentary on Plato's Theories of Love?", CQ 51 (2001) 557-75.

Rowe, C. J., Plato and the Art of Philosophical Writing, Cambridge, 2007.

Russell, D. A., Plutarch, New York, 1973.

Rutherford, R. B., The Art of Plato, London, 1995.

Swain, S., "Bilingualism and Biculturalism in Antonine Rome: Apuleius, Fronto, and Gellius", in L. Holford-Strevens \& A. Vardi (eds.), 2004, pp. 3-40.

Tecuşan , M., "Logos Sympotikos: Patterns of the Irrational in Philosophical Drinking: Plato Outside the Symposium”, in O. Murray, Sympotica. A Symposium On The Symposion, Oxford, 1990, pp. 238-60.

Teodorsson, S.-T., A Commentary on Plutarch's Table Talks I-III, Göteborg, 1989-1996.

Vardi, A., "Genre, Conventions, and Cultural Programme in Gellius' Noctes Atticae", in L. Holford-Strevens \& A. VArdi (eds.), 2004, pp.15986.

Walsh, P. G., Cicero. On Obligations (De Officiis), Oxford, 2000.

White, F. C., "Beauty of Soul and Speech in Plato's Symposium", CQ, 58 (2008) 69-82.

Wilkins, J., "Dialogue and Comedy: The Structure of the Deipnosophistae", in D. Braund \& J. Wilkins (eds.), 2000, pp. 23-40. 